\title{
Effects of Nitrogen Supply on Source-sink Balance and Fruit Size of 'Gala' Apple Trees
}

\author{
Guohai Xia and Lailiang Cheng ${ }^{1}$ \\ Department of Horticulture, Cornell University, 134A Plant Science, Tower Road, Ithaca, NY 14853
}

\begin{abstract}
Alan Lakso and Martin Goffinet
Department of Horticultural Sciences, New York State Agricultural Experiment Station, Geneva, NY 14456
\end{abstract}

AdDitional INDEX words. cell number, cell size, dry matter accumulation, harvest index, leaf area to fruit ratio, Malus domestica, photosynthetic capacity

\begin{abstract}
The objective of this study was to determine how nitrogen (N) supply affects the source-sink balance and fruit size of 'Gala' apple when crop load was controlled at a moderate level. Five-year-old 'Gala'/'M.26' trees grown in sand culture and trained in tall spindle received a total of 3.3, 10.0, 20.0, or $40.0 \mathrm{~g}$ actual $\mathrm{N}$ through fertigation using Hoagland's solution from bloom to 3 weeks before harvest. The crop load of these trees was adjusted to 6.5 fruit $/ \mathrm{cm}^{2}$ trunk cross-sectional area by hand thinning when the diameter of the largest fruit was $10 \mathrm{~mm}$. As $\mathrm{N}$ supply increased, total shoot leaf area in the canopy increased, whereas total spur leaf area remained unchanged. Both single leaf and whole canopy net $\mathrm{CO}_{2}$ assimilation rates increased with increasing $\mathrm{N}$ supply. The net dry matter gain of the whole tree from budbreak to fruit harvest increased $\approx \mathbf{7 4 \%}$ from the lowest $N$ supply to the highest $N$ supply, but the proportion of net dry matter gain partitioned to fruit (harvest index) decreased from $83 \%$ to $70 \%$. Both leaf area to fruit ratio and average final fruit size increased with increasing $\mathbf{N}$ supply, and a linear relationship was found between leaf area to fruit ratio and final fruit size. The number of cells per fruit increased with increasing $\mathbf{N}$ supply, whereas average cell size remained unchanged. As $\mathbf{N}$ supply increased, fruit soluble solids concentration increased, whereas fruit firmness decreased slightly. These results indicate that 1) apple trees grown under low $\mathrm{N}$ supply are source-limited; and 2) within the range of $\mathbf{N}$ supply used, increasing $\mathbf{N}$ supply improves leaf $\mathbf{N}$ status, leaf and whole tree photosynthetic capacity, and leaf area to fruit ratio, leading to more cells per fruit, larger fruit, and higher soluble solids.
\end{abstract}

'Gala' apple trees tend to produce small-sized fruit resulting from a combination of several factors (Robinson et al., 2005). First, Gala is a small-fruited cultivar. Second, 'Gala' trees differentiate flowers readily, have heavy fruit set, and are difficult to thin, especially when tree vigor is low, and as a result, 'Gala' trees often carry heavy crop loads. Finally, heavy cropping reduces tree vegetative growth (Avery, 1970; Buwalda and Lenz, 1992; Lenz, 1986; Wünsche and Palmer, 2000), which further decreases source (leaves) to sink (fruit) ratio. However, large-sized 'Gala' fruit is preferred over small fruit at a significant premium on the market. This has prompted growers to strive for large fruit size.

Apple fruit size at harvest is the result of an early exponential cell division in the first 4 to 6 weeks after bloom and subsequent cell expansion during the remainder of fruit growth (Al-Hinai and Roper, 2004; Blanpied and Wilde, 1968; Denne, 1960; Goffinet et al., 2005; Lakso et al., 1995). Fruit growth is affected by genotype and many internal and environmental factors (e.g., carbon supply, crop load, hormones, mineral nutrients, temperature, and light). For a given cultivar, crop load is perhaps the single most important factor that determines fruit growth and final fruit size (Haller and Magness, 1925; Magness, 1928; Magness and Overley, 1929; Preston, 1954;

Received for publication 10 July 2008. Accepted for publication 29 Oct. 2008 This work was supported in part by Hatch Funds and the New York Apple Research and Development Program.

We thank Richard Raba, Rick Piccioni, and Mary Jean Welser for technical assistance. The 'Gala' trees used in this study were generously donated by Van Well Nursery, Wenatchee, WA.

${ }^{1}$ Corresponding author. E-mail: LC89@Cornell.edu.
Wünsche and Palmer, 2000). The effect of crop load on fruit size exemplifies the central role of the source-sink relationship in determining apple fruit growth, which also provides a very useful framework for understanding the effect of many other factors on apple fruit growth and final fruit size.

Increasing nitrogen $(\mathrm{N})$ supply has been tried to improve 'Gala' fruit size, but the results are inconsistent. Robinson et al. (2005) reported that increasing the rate of $\mathrm{N}$ fertilization from 62.8 to $188.4 \mathrm{~kg} \cdot \mathrm{ha}^{-1}$ did not significantly increase 'Gala' fruit size. Similarly, Forshey (1982) did not detect any significant effect of $\mathrm{N}$ fertilization on the fruit size of 'Empire', another small-fruited apple cultivar, although leaf $\mathrm{N}$ was increased by $\mathrm{N}$ fertilization. We have conducted field trials for 3 years to determine the effect of $\mathrm{N}$ fertilization on 'Gala' fruit size and found that when crop load was maintained at a moderate level, increasing the rate of $\mathrm{N}$ fertilization led to an increase in fruit size; but under heavy crop load, the effect of $\mathrm{N}$ fertilization on fruit size was not significant. The lack of significant responses of fruit size to increasing $\mathrm{N}$ supply observed in the field could arise in two situations. First, tree N status is not limiting to fruit growth, and therefore further elevating tree $\mathrm{N}$ status through increasing $\mathrm{N}$ supply does not affect fruit size in a significant way. Second, tree N status is limiting, but heavy crop load may override the effect of increasing $\mathrm{N}$ supply on fruit size. Flower and fruit-thinning experiments have clearly demonstrated that when a tree is source-limited resulting from too much competition between fruit in a heavy cropping situation, fruit is typically small and thinning improves fruit size by lessening the source limitation through reducing the number of competing fruit. However, it is not known whether low-N trees are sourcelimited in terms of carbon supply. Under low $\mathrm{N}$ supply, apple 
trees generally have less vegetative growth, smaller leaf area, and lower $\mathrm{CO}_{2}$ assimilation capacity, indicating the carbon supply capacity of source leaves to fruit is lower compared with trees grown under adequate $\mathrm{N}$ supply. However, at the same time, low-N supply could directly decrease cell division and fruit growth, leading to low fruit set and low sink activity. The objective of this study was to understand how $\mathrm{N}$ supply affects the source-sink relationship of 'Gala' apple trees, leading to differences in final fruit size.

\section{Materials and Methods}

Plant Culture and treatments. Five-year-old 'Gala'/M.26 trees were grown in 55-L plastic containers in sand at a spacing of $1.07 \times 3.35 \mathrm{~m}$ in east-west rows at Cornell Orchards in Ithaca, NY (lat. $42^{\circ} 26^{\prime} \mathrm{N}$, long. $76^{\circ} 29^{\prime} \mathrm{W}$; elevation $500 \mathrm{~m}$ ). They were trained in tall spindle and were $\approx 3.5 \mathrm{~m}$ tall. These trees had regular crops over the last 2 years. Uniform trees were selected before budbreak in 2005, and each tree was fertigated with 4 L of Hoagland's No. 2 solution (Hoagland and Arnon, 1950) at one of four different $\mathrm{N}$ levels twice per week from bloom (5 May) to 3 weeks before harvest. The $\mathrm{N}$ concentration provided during active shoot growth was $2.5,7.5,12.5$, or 25 $\mathrm{mm}$, but when shoot growth stopped, the $\mathrm{N}$ concentrations were lowered. The weekly supply of $\mathrm{N}$ for the trees grown under the four $\mathrm{N}$ treatments was shown in Figure 1. Each tree received a total of $3.3,10.0,20$, or $40 \mathrm{~g}$ actual $\mathrm{N}$ during the experimental period, which is equivalent to $9.2,27.9,55.8$, or $111.6 \mathrm{~kg} \cdot \mathrm{ha}^{-1}$ of actual N. Each N treatment was replicated six times with a single tree per replicate in a completely randomized design. Irrigation was provided with spray sticks and the trees were well watered throughout the growing season. The crop load of these trees was adjusted to 6.5 fruit $/ \mathrm{cm}^{2}$ trunk cross-sectional area (TCA) by hand thinning when the diameter of the largest fruit was $10 \mathrm{~mm}$ (74 \pm 2 fruit per tree), and this crop load was maintained to fruit harvest. All the trees received standard disease and insect control throughout the growing season.

LEAF AND CANOPY PHOTOSYNTHESIS MEASUREMENTS. Singleleaf photosynthesis was measured with a CIRAS-1 gas

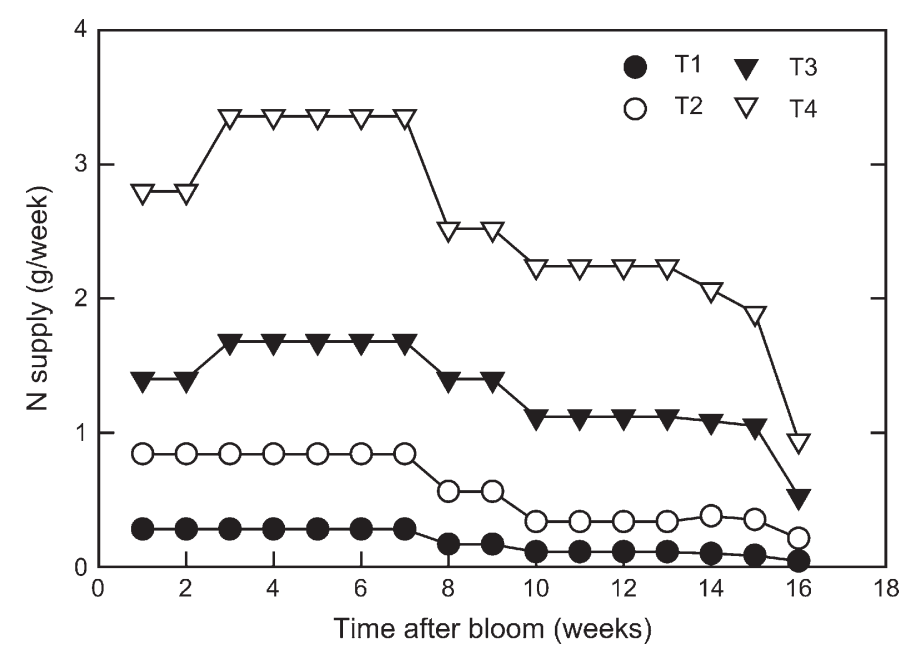

Fig. 1. Supply patterns of four levels of nitrogen (N) (T1, T2, T3, and T4) for 5year-old 'Gala'/M.26 apple trees during the growing season of 2005. The total amount of $\mathrm{N}$ provided by $\mathrm{T} 1, \mathrm{~T} 2, \mathrm{~T} 3$, and T4 during the growing season is 3.3 , 10,20 , and $40 \mathrm{~g}$ per tree, respectively. exchange system (PP Systems, Hitchin, U.K.) on leaves at the midposition of extension growth between 1100 and $1200 \mathrm{HR}$ under $1700 \pm 50 \mu \mathrm{mol} \cdot \mathrm{m}^{-2} \cdot \mathrm{s}^{-1}$ photosynthetic photon flux and an air temperature of $26 \pm 0.5^{\circ} \mathrm{C}$ at $70 \mathrm{~d}$ after bloom. Diurnal changes of whole canopy photosynthesis were monitored through an automated system with four whole tree chambers as described by Dragoni et al. (2005). Briefly, the whole tree chambers were made of $0.05 \mathrm{~mm}$ Mylar ${ }^{\circledR}$ plastic film (DuPont Teijin Films, Hopewell, VA) with a final volume of $2465 \mathrm{~L}$. $\mathrm{CO}_{2}$ concentrations at the inlet and outlet of each chamber were measured with a CIRAS-1 IR gas analyzer, and continuous recording of four chambers $24 \mathrm{~h}$ per day was made possible by using a custom-made portable control and data logging system. The sampling cycle per tree was $4 \mathrm{~min}$; all the calibration and equilibration were adjusted during the first minute and measurements were recorded for the following $3 \mathrm{~min}$. Over $24 \mathrm{~h}, 90$ readings per tree were recorded. Flow rate was determined between the blower and the chamber with a microanemometer calibrated to volume flow. Inlet air temperatures and the temperature at a shaded position inside the chamber were measured with thermocouples and recorded.

LEAF SAMPLING AND NUTRIENT ANALYSIS. Leaf samples were taken from midposition leaves on extension growth at $70 \mathrm{~d}$ after bloom for nutrient analysis. Leaf $\mathrm{N}$ was determined with a nitrogen analyzer (FP-428; LECO Corp., St. Joseph, MI) through combustion, and other macronutrients and micronutrients were measured through an Accuris inductively coupled plasma emission spectrometry (Fison Instrument, Dearborn, MI).

YIELD, FRUIT SIZE, AND FRUIT QUALITY MEASUREMENTS. Fruit number, fruit yield per tree, and average fruit weight were measured at fruit harvest on 15 Sept. Fruit firmness was measured from the two peeled sides of each fruit by a penetrometer (EPT-1-R; Lake City Technical Products, Kelowna, BC, Canada). Soluble solids concentration (percent) was measured from the expressed juice of the fruit used for firmness test with a portable digital refractometer (ATA-60 PAL-1; Atago USA, Bellevue, WA). The percent dry weight of the fruit was determined using a 20-fruit sample taken from each tree at harvest and the fruit were cut and placed in a forced-air oven at $75{ }^{\circ} \mathrm{C}$ for at least 2 weeks until constant weight. The total dry weight of the fruit per tree was calculated based on total fruit fresh weigh and the percent dry weight.

DETERMinATION OF FRUIT CELL VOLUME AND CELL NUMBER. At the time of fruit harvest, two fruit per tree were selected representing each tree's mean fruit size. After weighing, each fruit was processed for histological examination and measurement of cell size, cell number, and proportion of intercellular space of the cortex tissue following the method of Goffinet et al. (1995) with slight modifications. To derive the mean length to width ratio for cortex cells of 'Gala' apple, we sliced each of several additional mature fruit in two planes (transversely and radially) through the cortex from a midpoint between adjoining sepal and petal traces. These were stained in 5\% aqueous tannic acid, rinsed, and immersed in $2 \%$ ferric chloride to stain cellulosic cell walls. Segments were pinned in a water-filled dish and examined with a stereobinocular microscope of sufficient magnification to measure cell diameters with a calibrated ocular micrometer. At each of three positions along the cortex radius, we measured radial, tangential, and longitudinal cell diameter of 20 parenchyma cells depending on 
section plane. The mean length-width ratio of 1.194 was obtained and was used in all further microscopy as a constant in determining cell volume for sampled fruit. From hundreds of cell measurements, we determined overall cell shape to be a prolate spheroid with long cell dimension in the fruit radius and found cell height and tangential width to be identical. For each of the two fruit per tree to be analyzed, we estimated cortex volume by making six to seven equally spaced cuts across the fruit cross-section, removing from each slab all tissues inside the sepal-petal traces and determining displaced water volume of the remaining cortex pieces. We then used the slice closest to the greatest equatorial fruit diameter for our morphometric analysis for each specimen. From this, we removed the cortex sector of median thickness, carefully resliced it in the transverse plane with a double-edged razor blade, and stained and observed the flesh cells of the segment through microscopy as mentioned previously. The mean cell volume and total number of cells in the cortex were calculated according to Goffinet et al. (1995).

Whole tRee DestruCtive SAMPLing AND LEAF AREA MEASUREMENTS. Right after fruit harvest, all the trees were destructively sampled and partitioned into spurs (less than $5 \mathrm{~cm}$ ), shoots (greater than $5 \mathrm{~cm}$ ), lateral branches, central leader, rootstock shank, and roots. Roots were thoroughly washed, blotted dry, and then dried along with other tissues in a forced-air oven at $75^{\circ} \mathrm{C}$. Leaves were separated from spurs and shoots, and their total leaf area was determined separately with a leaf area meter (LI-3000; LI-COR, Lincoln, NE). The dry weight of all the samples was recorded after reaching constant weight. The total dry weight of each tree was the sum of the dry weight of each tissue type, including fruit. A set of four trees was randomly selected and destructively sampled at the beginning of the experiment just before budbreak to determine their baseline total dry weight. The net dry matter gain per tree from budbreak to fruit harvest was calculated as the difference between total tree dry weight at fruit harvest and at budbreak. Harvest index was calculated as percent of the net dry matter gain from budbreak to fruit harvest partitioned into fruit.

Data analysis. Analysis of variance and linear regression were performed through SAS (version 8.0; SAS Institute, Cary, NC).

\section{Results}

In response to $\mathrm{N}$ supply, total leaf area per tree increased from $2.2 \mathrm{~m}^{2}$ in the lowest $\mathrm{N}$ supply to $4.0 \mathrm{~m}^{2}$ in the highest $\mathrm{N}$ supply (Fig. 2). The total leaf area of an apple tree consists of two types of leaf area: spur leaf area and shoot leaf area. Increasing $\mathrm{N}$ supply did not significantly affect total spur leaf area but increased total shoot leaf area (Fig. 2).

As $\mathrm{N}$ supply increased, leaf $\mathrm{N}$ concentration increased from $1.2 \%$ to $2.2 \%$ (Fig. 3A); leaf manganese concentration also increased (Fig.

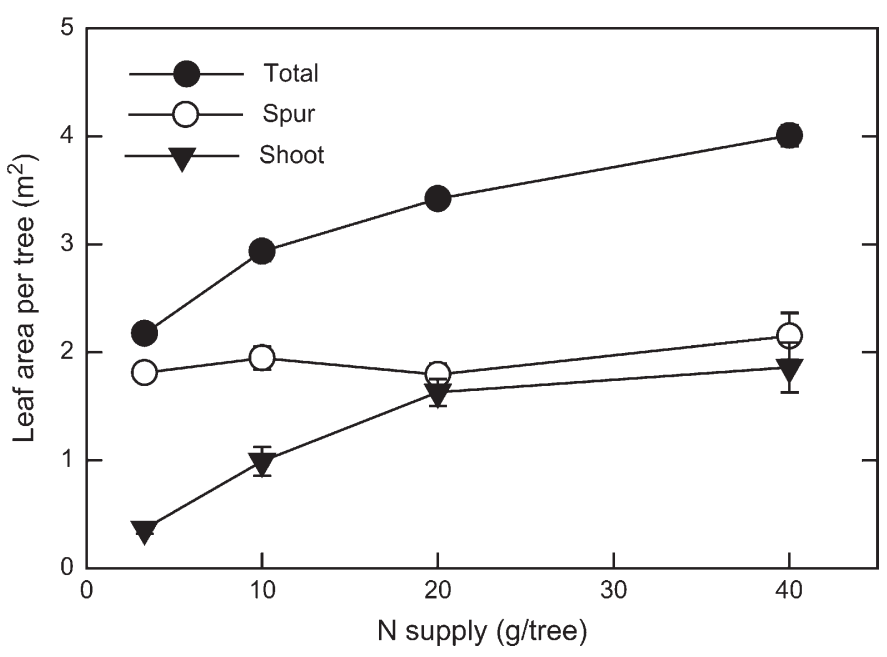

Fig. 2. Total leaf area, spur leaf area, and shoot leaf area of 5-year-old 'Gala'/ M.26 apple trees in response to nitrogen (N) supply. Trees received 3.3, 10, 20 , or $40 \mathrm{~g} \mathrm{~N}$ per tree during the growing season. Each point is mean $\pm \mathrm{SE}$ of $\mathrm{six}$ replicates. Data were analyzed by one-way analysis of variance, $P<0.0001$, $P=0.20$, and $P=0.0002$ for total leaf area, spur leaf area, and shoot leaf area, respectively.

3B), but both leaf phosphorus and leaf boron concentrations decreased (Fig. 3C-D). All the other nutrients in leaves were either unaffected or only affected slightly, but all of them fell within a range considered satisfactory for the cultivar (data not shown).

In response to increasing $\mathrm{N}$ supply, single leaf net $\mathrm{CO}_{2}$ assimilation rate increased (Fig. 4), whereas the calculated intercellular $\mathrm{CO}_{2}$ concentrations decreased (data not shown). As a result of increases in both leaf $\mathrm{CO}_{2}$ assimilation capacity and total leaf area per tree, whole tree net $\mathrm{CO}_{2}$ exchange rate increased with increasing $\mathrm{N}$ supply (Fig. 5).
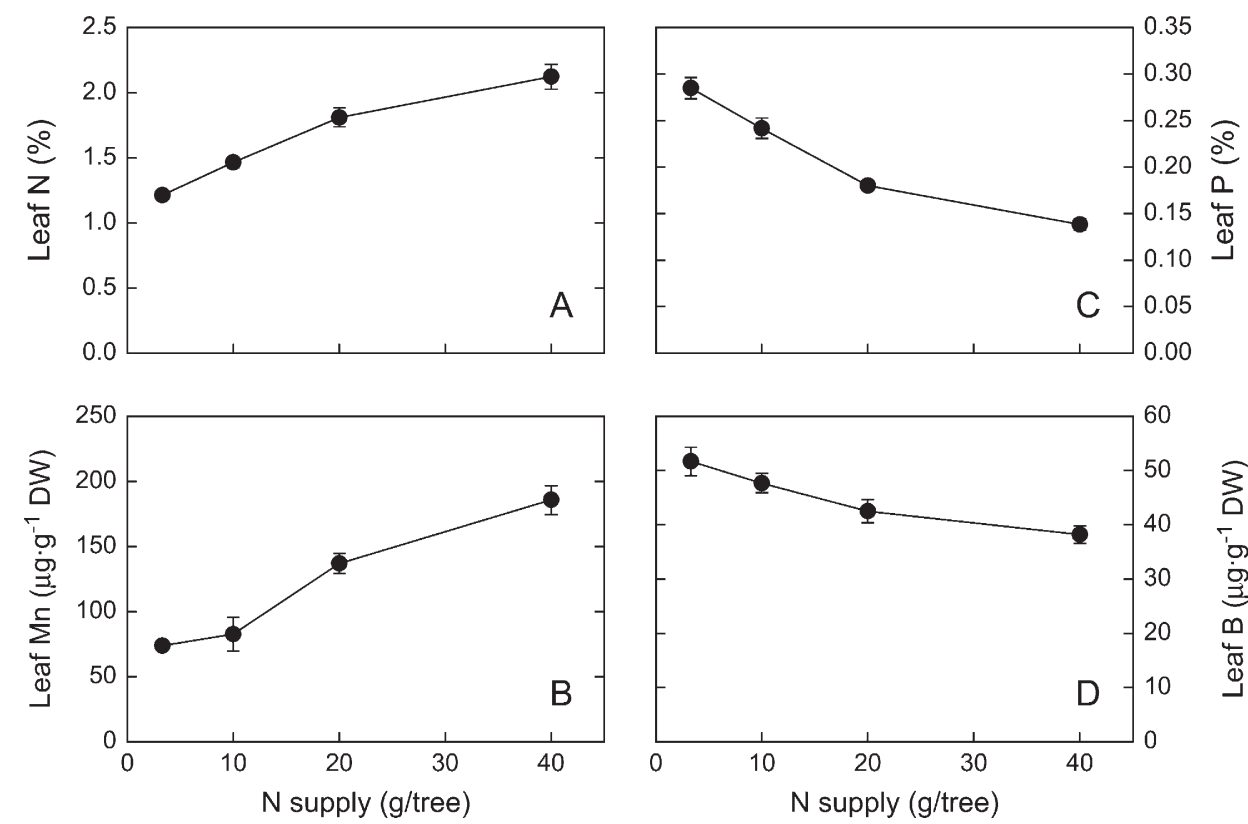

Fig. 3. Concentrations of leaf nitrogen (N) (A), manganese (Mn) (B), phosphorus (P) (C), and boron (B) (D) of 5-year-old 'Gala'/M.26 apple trees in response to N supply. Trees received 3.3, 10, 20, or $40 \mathrm{~g}$ N per tree during the growing season. Leaf samples were taken at $70 \mathrm{~d}$ after bloom. Each point is mean $\pm \mathrm{SE}$ of six replicates. Data were analyzed by one-way analysis of variance. $P<0.0001$ for leaf N, P, and $\mathrm{Mn} ; P=0.001$ for leaf $\mathrm{B}$. 


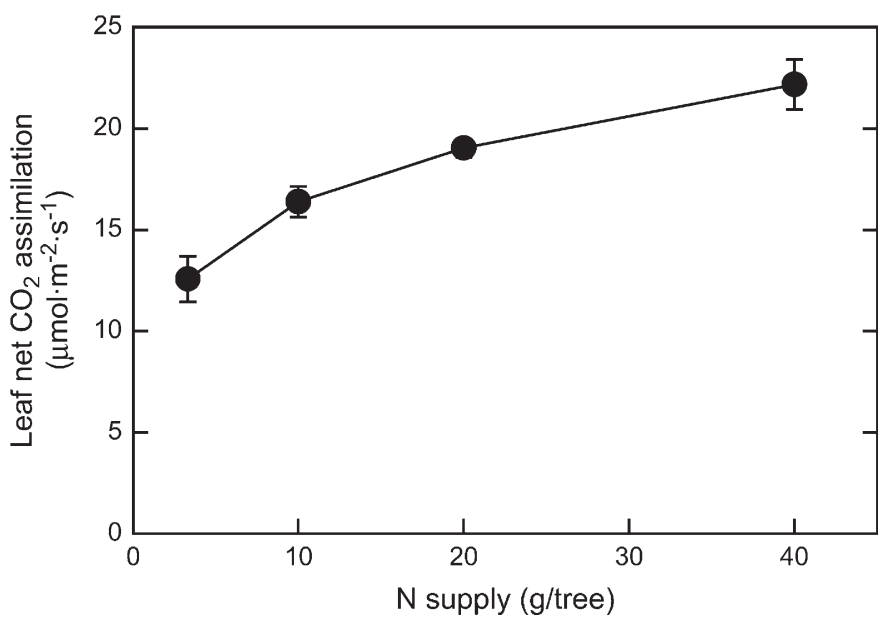

Fig. 4. Net $\mathrm{CO}_{2}$ assimilation rate of leaves at the midposition of extension growth in 5-year-old 'Gala'/M.26 apple trees in response to nitrogen $(\mathrm{N})$ supply. Trees received $3.3,10,20$, or $40 \mathrm{~g} \mathrm{~N}$ per tree during the growing season. Measurements were made at $70 \mathrm{~d}$ after bloom at a photosynthetic photon flux of $1700 \pm 50 \mu \mathrm{mol} \cdot \mathrm{m}^{-2} \cdot \mathrm{s}^{-1}$ and an air temperature of $26 \pm 0.5^{\circ} \mathrm{C}$. Each point is mean \pm SE of six replicates. Data were analyzed by one-way analysis of variance, $P<0.0001$.

As $\mathrm{N}$ supply increased, average fruit size increased from $\approx 129 \mathrm{~g}$ to $\approx 180 \mathrm{~g}$ (Fig. $6 \mathrm{~A}$ ). This was primarily caused by an increase in the number of cells per fruit at higher $\mathrm{N}$ supply levels, whereas average cell size was unaffected by $\mathrm{N}$ supply (Fig. 7). Leaf area to fruit ratio showed a curvilinear response to $\mathrm{N}$ supply (Fig. 8A). When average fruit size was plotted against leaf area to fruit ratio, a linear relationship was found (Fig. 8B), i.e., fruit size is proportional to the leaf area that supports each fruit. Good size 'Gala' (180 g/fruit) corresponds to a leaf area to fruit ratio of $558 \pm 21 \mathrm{~cm}^{2} /$ fruit. Because crop load was adjusted to the same level at 6.5 fruit $/ \mathrm{cm}^{2} \mathrm{TCA}$, the increase in fruit yield

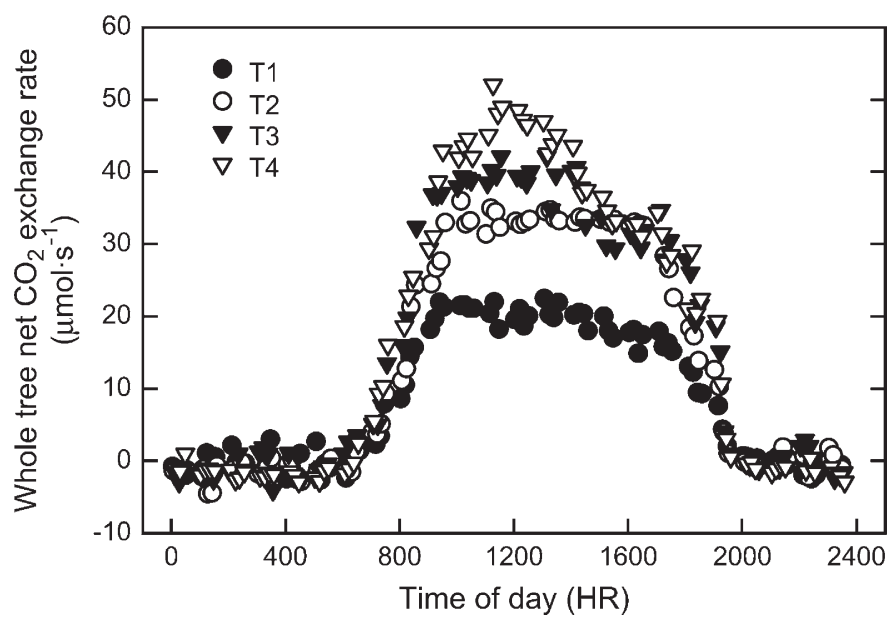

Fig. 5. Diurnal changes of whole tree net carbon assimilation of representative 5-year-old 'Gala'/M.26 apple trees in response to nitrogen (N) supply. T1, T2, $\mathrm{T} 3$, and $\mathrm{T} 4$ represent the four levels of $\mathrm{N}$ supply, which provided a total of $3.3,10,20$, and $40 \mathrm{~g} \mathrm{~N}$ per tree, respectively, during the growing season. Measurements were made on 23 Aug. 2005. It was a clear day with a maximum photosynthetic photon flux of $1840 \pm 50 \mu \mathrm{mol} \cdot \mathrm{m}^{-2} \cdot \mathrm{s}^{-1}$ at solar noon $(1300 \mathrm{HR})$. The lowest and highest air temperatures were $13.5^{\circ} \mathrm{C}$ at $0430 \mathrm{HR}$ and $33.3{ }^{\circ} \mathrm{C}$ at $1445 \mathrm{HR}$, respectively. The temperature inside the chambers was within $1.5^{\circ} \mathrm{C}$ of the air temperature. per tree in response to $\mathrm{N}$ supply (Fig. 6B) was entirely the result of the increase in fruit size. Fruit soluble solids concentration increased from $13.7 \%$ in the lowest $\mathrm{N}$ treatment to $15.5 \%$ in the highest $\mathrm{N}$ treatment (Fig. 9A). Fruit firmness decreased slightly from the lowest $\mathrm{N}$ supply to the highest $\mathrm{N}$ supply (Fig. 9B).

Total dry weight per tree at fruit harvest increased as $\mathrm{N}$ supply increased (Fig. 10A). The increase in total dry matter mainly occurred in leaves, fruit, and scion woody parts, whereas the dry weight of rootstock shank and roots remained unchanged (Fig. 10B-E). The net dry matter gain from budbreak to fruit harvest on a whole tree basis increased $74 \%$ from the lowest to the highest $\mathrm{N}$ supply (Fig. 11A), but the proportion of the net dry matter gain partitioned to fruit, also called harvest index, decreased from $83 \%$ in the lowest $\mathrm{N}$ supply to $70 \%$ in the highest $\mathrm{N}$ supply (Fig. 11B).

\section{Discussion}

'Gala' apple trees grown under low N supply had smaller total leaf area per tree (Fig. 2), lower single leaf and whole canopy net carbon assimilation (Figs. 4 and 5), lower leaf area to fruit ratio (Fig. 8A), and smaller fruit size (Fig. 6A) but higher harvest index (Fig. 11B). These collectively indicate that
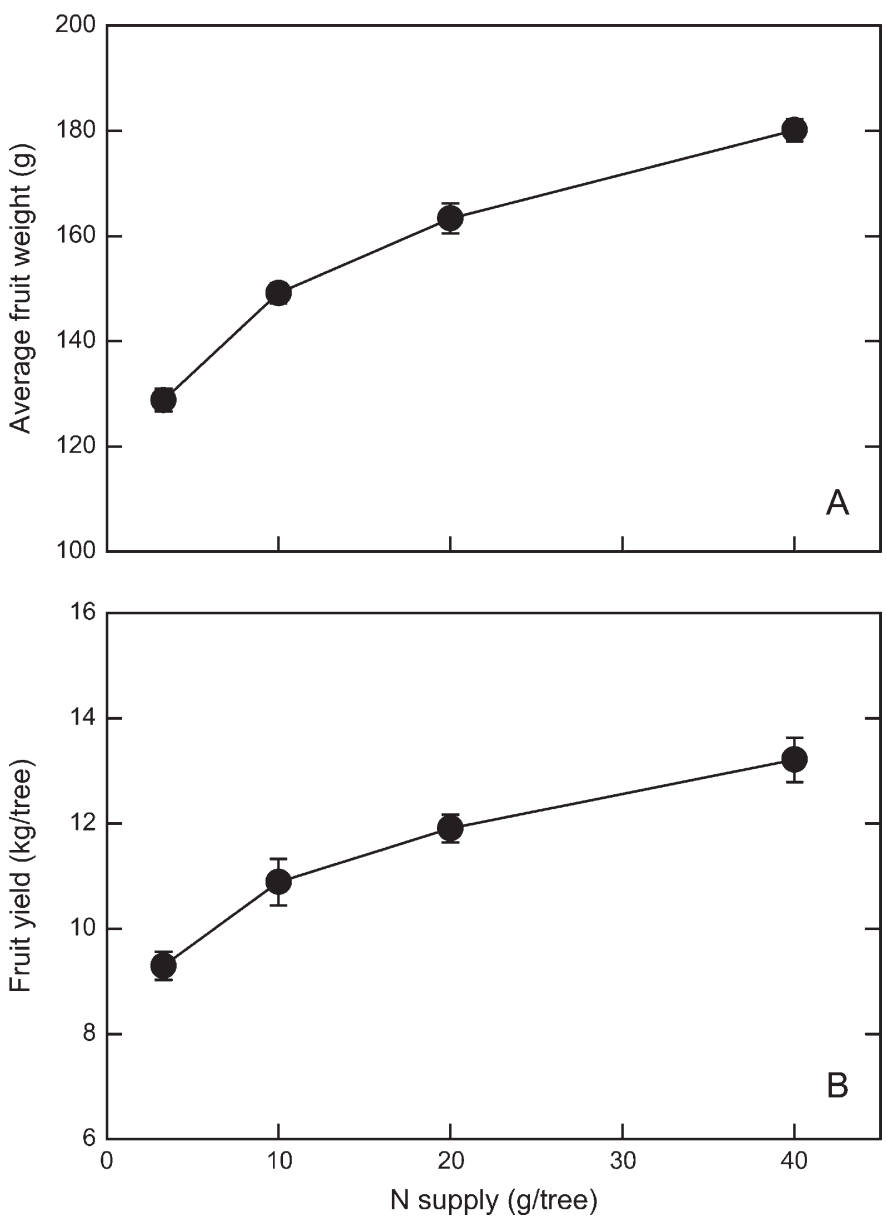

Fig. 6. Average fruit weight at harvest (A) and fruit yield per tree (B) of 5-yearold 'Gala'/M.26 apple trees in response to nitrogen (N) supply. Trees received $3.3,10,20$, or $40 \mathrm{~g} \mathrm{~N}$ per tree during the growing season. Each point is mean \pm SE of six replicates. Data were analyzed by one-way analysis of variance, $P<$ 0.0001 for both average fruit weight and total yield. 

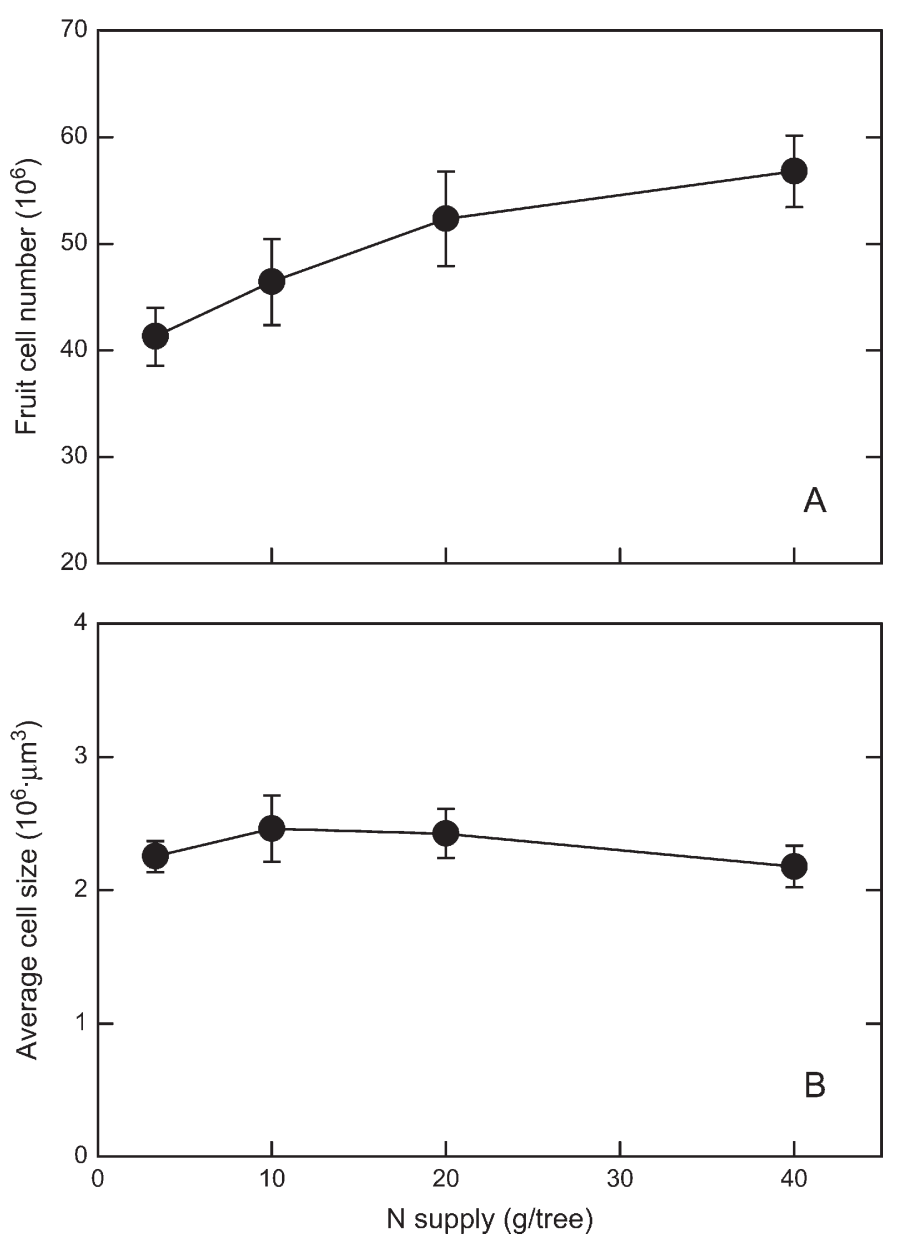

Fig. 7. Fruit cell number (A) and cell size (B) of harvested fruit of 5-year-old 'Gala'/M.26 apple trees in response to nitrogen (N) supply. Trees received $3.3,10,20$, or $40 \mathrm{~g} \mathrm{~N}$ per tree during the growing season. Each point is mean \pm SE of six replicates. Data were analyzed by one-way analysis of variance, $P=$ 0.03 and $P=0.65$ for fruit cell number and average cell size, respectively.

the trees grown under low $\mathrm{N}$ supply are more source-limited than those at higher $\mathrm{N}$ supplies. This study clearly showed that, within the range of $\mathrm{N}$ supply used, increasing $\mathrm{N}$ supply improves leaf $\mathrm{N}$ status (Fig. 3A), leaf and whole tree $\mathrm{CO}_{2}$ assimilation (Figs. 4 and 5), and leaf area to fruit ratio (Fig. 8A), leading to more cells per fruit (Fig. 7A), larger fruit (Fig. 6A), and higher soluble solids (Fig. 9A).

Apple fruit growth and development depends on carbon supply from leaves. 'Gala' leaf $\mathrm{CO}_{2}$ assimilation is closely related to its $\mathrm{N}$ status (Fig. 4), which is consistent with the results obtained previously on nonbearing young apple trees (Chen and Cheng, 2004; Cheng and Fuchigami, 2000a). The enhanced leaf $\mathrm{CO}_{2}$ assimilation capacity at higher $\mathrm{N}$ supplies is most likely the result of higher activity of ribulose-1,5bisphosphate carboxylase/oxygenase and other Calvin cycle enzymes (Chen and Cheng, 2004; Cheng and Fuchigami, $2000 \mathrm{~b}$ ). It should be noted that whole canopy $\mathrm{CO}_{2}$ assimilation is not simply a product of total leaf area per tree by the $\mathrm{CO}_{2}$ assimilation rate of well-exposed single leaves measured (Figs. 4 and 5). This is because total leaf area per tree increased in response to increasing $\mathrm{N}$ supply (Fig. 2), which has made a larger proportion of the leaf area in the canopy shaded. Thus, whole canopy gas exchange measurement is more representa-
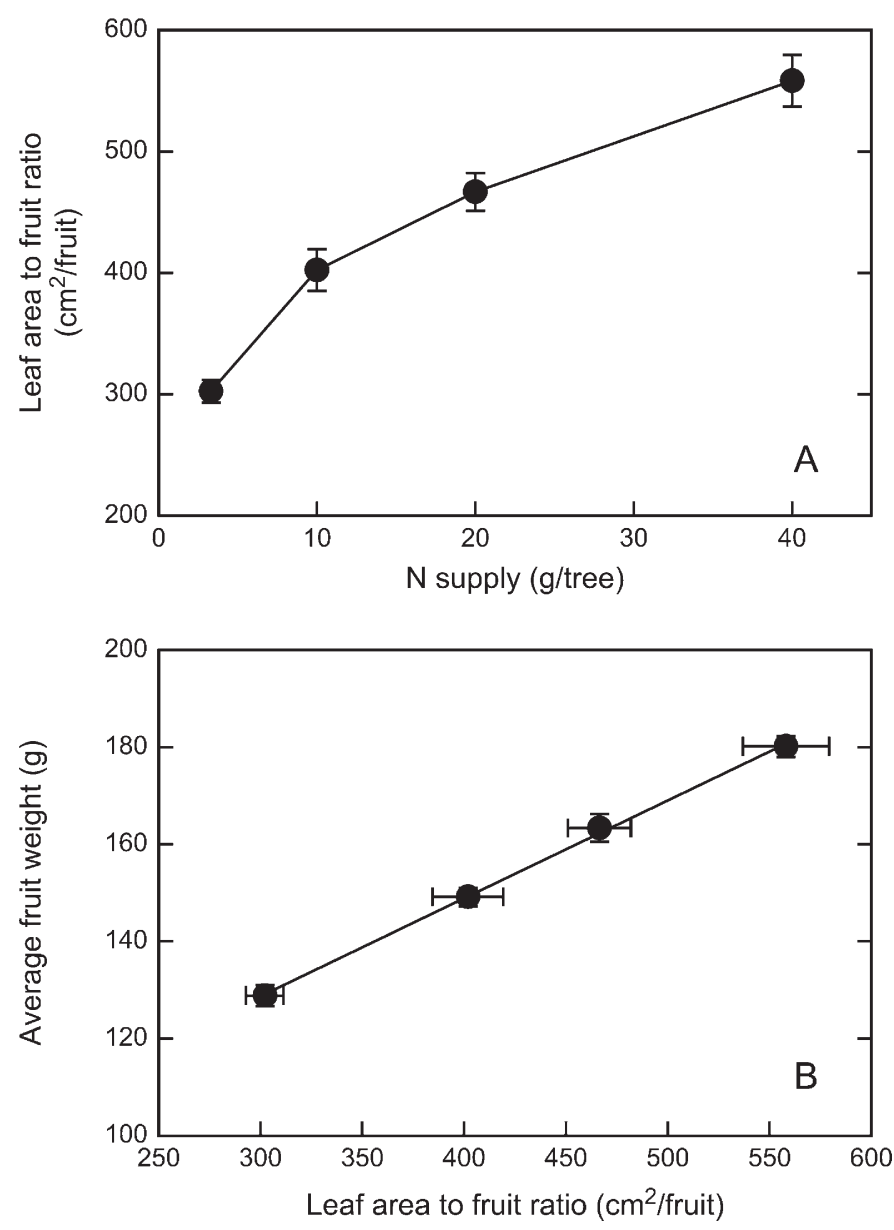

Fig. 8. Leaf area to fruit ratio in response to nitrogen (N) supply (A) and average fruit weight at harvest in relation to leaf area to fruit ratio (B) of 5-year-old 'Gala'/M.26 apple trees. Trees received 3.3, 10, 20, or $40 \mathrm{~g} \mathrm{~N}$ per tree during the growing season. Each point is mean $\pm \mathrm{SE}$ of six replicates. Leaf area to fruit ratio was analyzed by one-way analysis of variance, $P<0.0001$. The regression equation in $\mathrm{B}$ is $\mathrm{Y}=68.2+0.202 \mathrm{X}\left(r^{2}=0.99, P=0.0006\right)$.

tive of the whole tree carbon assimilation than single leaf gas exchange measurement. Indeed, the increase in whole canopy gas exchange matches well with the increase in net dry matter gain per tree from budbreak to fruit harvest (Fig. 11A).

We found a tight relationship between leaf area to fruit ratio and average fruit size in this study (Fig. 8B), which is consistent with those obtained in studies in which fruit number was manipulated by thinning (Haller and Magness, 1925; Magness, 1928; Magness and Overley, 1929; Preston, 1954). The small leaf area to fruit ratio coupled with low leaf photosynthetic capacity under low $\mathrm{N}$ supply clearly indicates that the low $\mathrm{N}$ trees are source-limited. Hansen (1969) found that the proportion of ${ }^{14} \mathrm{C}$-photosynthates translocated to fruit is the highest when leaf area to fruit ratio is the smallest and decreases with increasing leaf area to fruit ratio, which strongly supports our conclusion. The tight relationship between leaf area to fruit ratio and fruit size clearly demonstrates the importance of having sufficient leaf area for each fruit in determining final fruit size. There are two ways to increase the leaf area to fruit ratio: 1) improving tree vegetative growth and total leaf area per tree; and 2) reducing crop load. Because 'Gala' trees generally have heavy fruit set and good return bloom every year, tree vegetative growth tends to decrease, leading to decreases in 

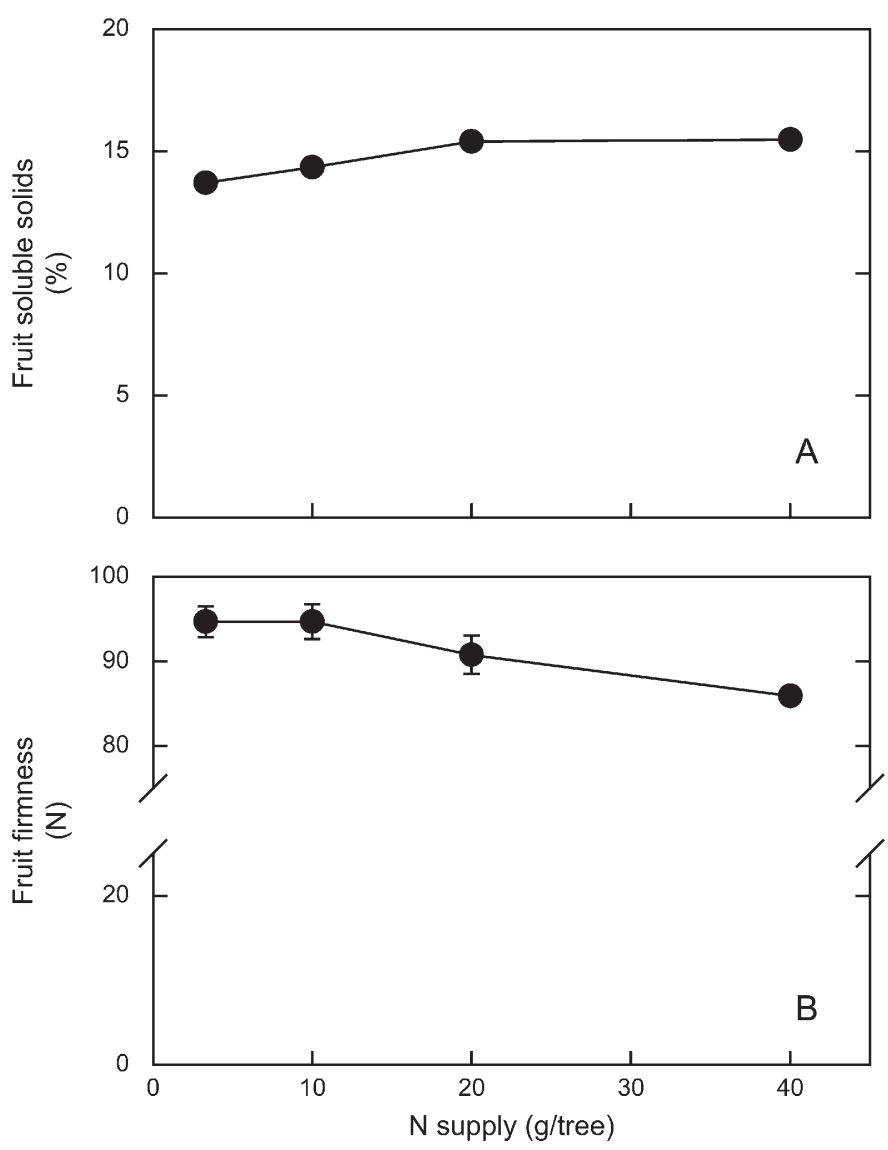

Fig. 9. Soluble solids concentration (A) and firmness (B) of harvested fruit of 5-year-old 'Gala'/M.26 apple trees in response to nitrogen (N) supply. Trees received 3.3, 10, 20, or $40 \mathrm{~g} \mathrm{~N}$ per tree during the growing season. Each point is mean \pm SE of six replicates. Data were analyzed by one-way analysis of variance, $P<0.0001$ for soluble solids, $P=0.0025$ for firmness.

total tree leaf area and fruit size. Stimulating shoot growth is important for maintaining good tree vigor and total tree leaf area. As shown in Figure 2, increasing N supply improved shoot growth and total leaf area. Pruning studies also demonstrated that stubbing back is very effective in promoting shoot growth while reducing crop load in 'Gala' (Robinson et al., 2005). In some cases, 'Gala' trees have good nutrient status and a healthy canopy, but end up producing small-sized fruit resulting from too heavy a crop load. Based on the results of this study and others (Robinson et al., 2005), we think the optimal crop load for producing good size $(180 \mathrm{~g})$ 'Gala' is six to eight fruit $/ \mathrm{cm}^{2}$ TCA.

This study clearly showed that the increase in average fruit size in response to $\mathrm{N}$ supply was primarily caused by an increase in the number of cells per fruit at higher $\mathrm{N}$ supply levels, whereas average cell size was unaffected by $\mathrm{N}$ supply (Fig. 7). The increase in fruit size of 'Empire' apple in response to thinning is also attributed to an increase in cell number, not cell size (Goffinet et al., 1995). Apple fruit cell division is nearly completed at $\approx 4$ to 6 weeks after bloom (Al-Hinai and Roper, 2004; Blanpied and Wilde, 1968; Denne, 1960; Goffinet et al., 2005). During this period, the young fruitlets require both high carbon supply and high $\mathrm{N}$ concentrations in the tissue for protein (enzyme) synthesis to support the active metabolism associated with rapid cell division. Under low $\mathrm{N}$ supply, not only $\mathrm{N}$ concentration in fruit is low, but carbon supply to fruit is also low, leading to decreased cell division.
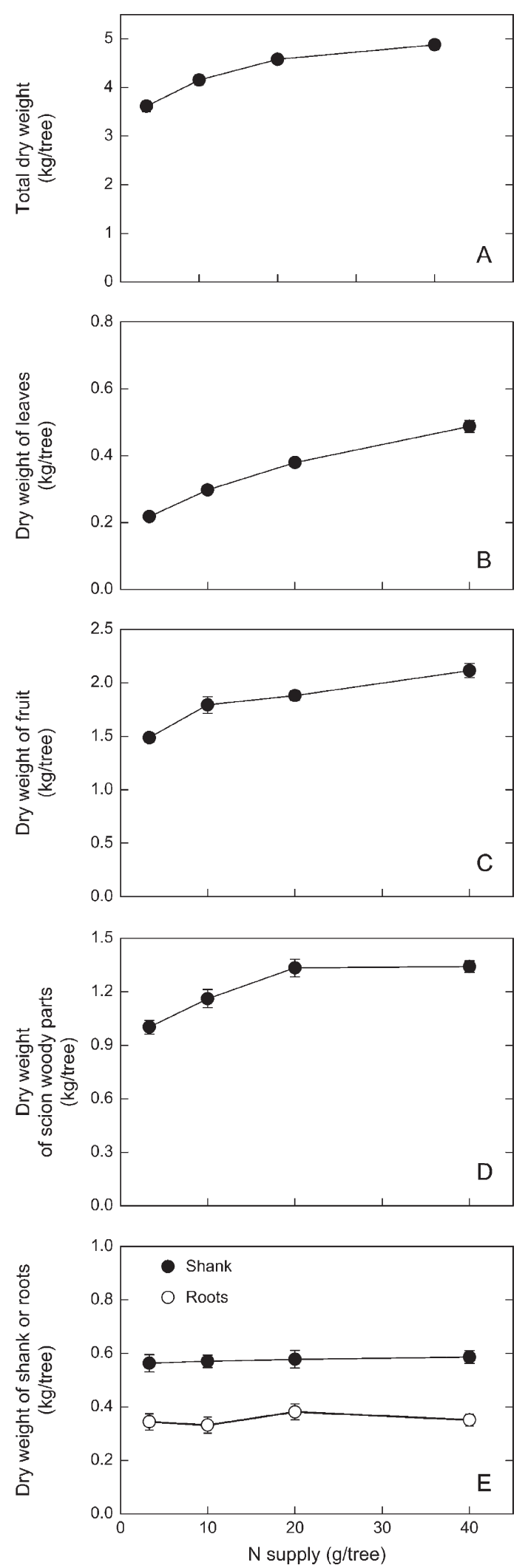

Fig. 10. Dry weight of the whole tree (A), leaves (B), fruit (C), scion woody parts (D), and rootstock shank or roots (E) of 5-year-old 'Gala'/M.26 apple trees at harvest in response to nitrogen $(\mathrm{N})$ supply. Trees received 3.3, 10, 20, or $40 \mathrm{~g} \mathrm{~N}$ per tree during the growing season. Each point is mean $\pm \mathrm{SE}$ of six replicates. Data were analyzed by one-way analysis of variance, $P<0.0001$ for the dry weight of the whole tree, leaves, fruit, and scion woody parts, $P=$ 0.95 for rootstock shank, $P=0.28$ for roots. 

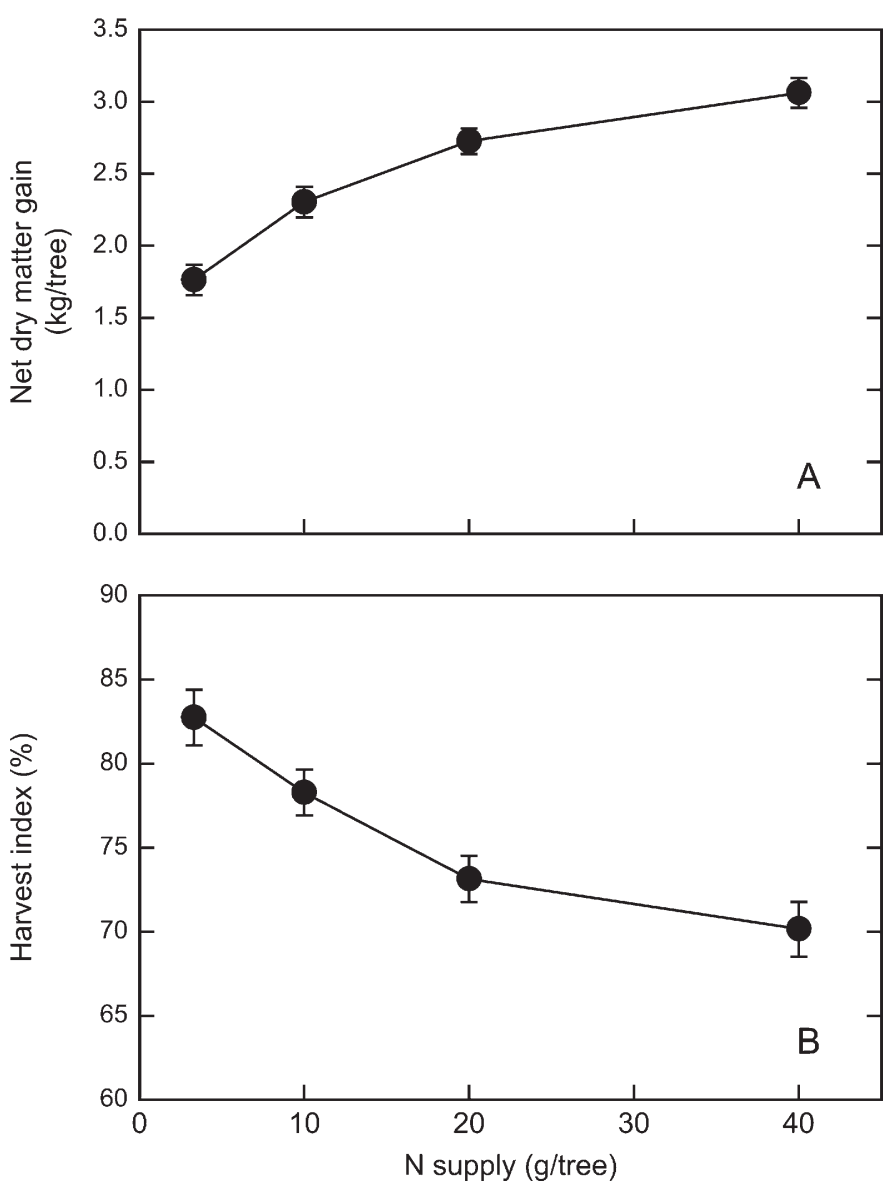

Fig. 11. Net dry matter gain from budbreak to fruit harvest (A) and the proportion of the net dry matter gain partitioned to fruit (harvest index, B) of 5-year-old 'Gala'/M.26 apple trees in response to nitrogen (N) supply. Trees received 3.3, 10, 20, or $40 \mathrm{~g} \mathrm{~N}$ per tree during the growing season. Each point is mean \pm SE of six replicates. Data were analyzed by one-way analysis of variance, $P<0.0001$ for net dry matter gain, $P=0.004$ for harvest index.

The harvest index value $(70 \%)$ obtained from the trees grown under sufficient $\mathrm{N}$ supply in this study (Fig. 11B) was similar to those $(63 \%$ to $77 \%)$ previously reported on dwarf apple trees (Avery, 1970; Forshey and Mackee, 1970; Heim et al., 1979; Lakso et al., 1999; Lenz, 1986; Palmer, 1988; Palmer et al., 2002). The increase in harvest index with decreasing $\mathrm{N}$ supply (Fig. 11B) corroborates the finding that the proportion of ${ }^{14} \mathrm{C}$-photosynthates translocated to fruit increases as leaf area to fruit ratio decreases (Hansen, 1969) and confirms that 'Gala' apple trees become more source-limited with decreasing $\mathrm{N}$ supply.

The higher soluble solids concentration in the higher $\mathrm{N}$ treatments (Fig. 9A) indicates that accumulation of sugars increased as a result of improved supply of carbon to fruit or starch degradation was accelerated in the fruit under higher $\mathrm{N}$ supply. Neilsen et al. (2006) observed that 'Gala' apple trees receiving low $\mathrm{N}$ supply at 0 to 4 weeks after bloom had higher starch (measured as lower starch index) in fruit at harvest than those receiving high $\mathrm{N}$ supply during the same period or low $\mathrm{N}$ supply at later times. Fallahi et al. (2001) also noticed 'Fuji' apple trees receiving low $\mathrm{N}$ supply had slightly higher starch (as measured by lower starch index) than those at higher $\mathrm{N}$ supply. Further monitoring of both starch concentration and soluble sugars during fruit development is needed to clarify the mechanism.
Our results showed that increasing $\mathrm{N}$ supply altered the concentrations of other nutrients in leaves in addition to leaf $\mathrm{N}$ (Fig. 3). Higher manganese concentration in leaves at higher $\mathrm{N}$ supply observed in this study is in agreement with the findings of Neilsen et al. (1984) and Fallahi et al. (2001) on 'Golden Delicious' and 'Fuji' apples. However, we did not detect a significant drop in leaf potassium concentration at higher $\mathrm{N}$ supply as reported by Fallahi et al. $(1984,2001)$ and Meheriuk et al. (1992). This discrepancy could be related to the fact that sufficient potassium was provided through the Hoagland's solution in this experiment, and the trees were grown in sand, in which its low cation exchange capacity may have significantly reduced the competition between ammonium and potassium for cation adsorption sites on colloids. However, we did find that increasing $\mathrm{N}$ supply lowered the concentrations of both phosphorus and boron in leaves (Fig. 3C-D), although both are still within the satisfactory range considered for the cultivar. This might have resulted from dilution effect resulting from increased tree growth at higher N supply, but clearly indicates more phosphorus and boron are needed at higher $\mathrm{N}$ supply.

Although this study was focused on $\mathrm{N}$ with all the other nutrients in leaves kept at optimal levels, it should be pointed out that deficiency of any other essential mineral nutrients may lower leaf and canopy photosynthesis as well, resulting in lower carbon supply to fruit. Having sufficient levels of $\mathrm{N}$ and other mineral nutrients in leaves is essential, but high rates of photosynthesis might not be guaranteed because many other factors (water supply, light availability, disease and insect damage, and so on) affect leaf and canopy photosynthesis in the field. In many cases, although leaf $\mathrm{N}$ and other nutrient status are sufficient, drought, and disease and insect damages prevent leaves from reaching their photosynthetic potential, reducing carbon supply to fruit. So, not only leaf nutrient status, but all the other cultural practices need to be optimized to achieve high canopy photosynthesis for producing large-sized 'Gala' apple at a moderate crop load.

In conclusion, 'Gala' apple trees grown under low $\mathrm{N}$ supply are source-limited when crop load was controlled at a moderate level, and increasing $\mathrm{N}$ supply improves leaf $\mathrm{N}$ status, leaf and whole tree photosynthetic capacity, and leaf area to fruit ratio, leading to more cells per fruit, larger fruit, and higher soluble solids.

\section{Literature Cited}

Al-Hinai, Y.K. and T.R. Roper. 2004. Rootstock effects on growth, cell number, and cell size of 'Gala' apples. J. Amer. Soc. Hort. Sci. 129:37-41.

Avery, D.J. 1970. Effects of fruiting on the growth of apple trees on four apple rootstock varieties. New Phytol. 69:19-30.

Blanpied, G.D. and M.H. Wilde. 1968. A study of the cells in the outer flesh of developing McIntosh fruits. Bot. Gaz. 129:173-183.

Buwalda, J.G. and F. Lenz. 1992. Effects of cropping, nutrition and water supply on accumulation and distribution of biomass and nutrients for apple trees on 'M.9' root system. Physiol. Plant. 84:21-28.

Chen, L.S. and L. Cheng. 2004. Photosynthetic enzymes and carbohydrate metabolism of apple leaves in response to $\mathrm{N}$ limitation. J. Hort. Sci. Biotechnol. 79:923-929.

Cheng, L. and L.H. Fuchigami. 2000a. $\mathrm{CO}_{2}$ assimilation in relation to $\mathrm{N}$ content in apple leaves. J. Hort. Sci. Biotechnol. 75:383-387.

Cheng, L. and L.H. Fuchigami. 2000b. Rubisco activation state decreases with increasing $\mathrm{N}$ content in apple leaves. J. Expt. Bot. 51:1687-1694.

Denne, M.P. 1960. The growth of apple fruitlets, and the effect of early thinning on fruit development. Ann. Bot. New Ser. 24:397-406. 
Dragoni, D., A.N. Lakso, and R.M. Piccioni. 2005. Transpiration of apple trees in a humid climate using heat pulse sap flow gauges calibrated with whole-canopy gas exchange chambers. Agr. For. Meteorol. 130:85-94.

Fallahi, E., W.M. Colt, and B. Fallahi. 2001. Optimum ranges of leaf $\mathrm{N}$ for yield, fruit quality and photosynthesis in 'BC-2 Fuji' apple. J. Amer. Pomol. Soc. 55:68-75.

Fallahi, E., M.N. Westwood, M.H. Chaplin, and D.G. Richardson. 1984. Influence of apple rootstocks, $\mathrm{K}$ and $\mathrm{N}$ fertilizers on apple leaf mineral composition and yield in a high density orchard. J. Plant Nutr. 7:1161-1177.

Forshey, C.G. 1982. Effects of fruiting, pruning, and N fertilization on shoot growth of 'Empire' apple trees. J. Amer. Soc. Hort. Sci. 107:1092-1097.

Forshey, C.G. and M.W. Mackee. 1970. Production efficiency of a large and a small 'McIntosh' apple tree. HortScience 5:164-165.

Goffinet, M.C., J.R. McFerson, and A.N. Lakso. 2005. Apple fruit growth and cell division in relation to embryo and endosperm development in two climates, New York State and Washington State. HortScience 40:1097 (abstr).

Goffinet, M.C., T.L. Robinson, and A.N. Lakso. 1995. A comparison of 'Empire' apple fruit size and anatomy in unthinned and handthinned trees. J. Hort. Sci. 70:375-387.

Haller, M.H. and J.R. Magness. 1925. The relation of leaf area to the growth and composition of apples. Proc. Amer. Soc. Hort. Sci. 22:189-196.

Hansen, P. 1969. ${ }^{14} \mathrm{C}$ studies on apple trees. IV. Photosynthate consumption in fruits in relation to the leaf-fruit ratio and to the leaf-fruit position. Physiol. Plant. 22:186-198.

Heim, G., J.J. Landsberg, R.L. Watson, and P. Brain. 1979. Ecophysiology of apple trees: Dry matter production and partitioning by young 'Golden Delicious' apple trees in France and England. J. Appl. Ecol. 16:179-194.

Hoagland, D.R. and D.I. Arnon. 1950. The water-culture method for growing plants without soil. California Agr. Expt. Sta. Circ. 347.

Lakso, A.N., L. Corelli Grappadelli, J. Barnard, and M.C. Goffinet. 1995. An expolinear model of the growth pattern of the apple fruit. J. Hort. Sci. 70:389-394.
Lakso, A.N., J. Wünsche, J.W. Palmer, and L. Corelli Grappadelli. 1999. Measurement and modeling of carbon balance of the apple tree. HortScience 34:1040-1047.

Lenz, F. 1986. Fruit effects on transpiration and dry matter production in apples, p. 101-104. In: Lakso, A.N. and F. Lenz (eds.). The regulation of photosynthesis in fruit trees. New York State Agr. Expt. Sta. Spec. Publ., Geneva, NY.

Magness, J.R. 1928. Relation of leaf area to size and quality in apple. Proc. Amer. Soc. Hort. Sci. 25:285-288.

Magness, J.R. and F.L. Overley. 1929. Relation of leaf area to size and quality of apples and pears. Proc. Amer. Soc. Hort. Sci. 26:160162.

Meheriuk, M., G.G. Neilsen, and E.J. Hogue. 1992. The influence of N fertilization, season of application, and orchard floor management on fruit quality and leaf mineral content of 'Golden Delicious' apple trees. Fruit Var. J. 46:71-75.

Neilsen, G.H., M. Meheriuk, and E.J. Hogue. 1984. The effect of orchard floor and $\mathrm{N}$ fertilizer on nutrient uptake and fruit quality of 'Golden Delicious' apple trees. HortScience 19:547-550.

Neilsen, D., G.D. Neilsen, L. Herbert, P. Millard, and S. Guak. 2006. Allocation of dry matter and $\mathrm{N}$ to fruit and shoots in dwarf apple in response to sink size and $\mathrm{N}$ availability. Acta Hort. 721: 33-40.

Palmer, J.W. 1988. Annual dry matter production and partitioning over the first 5 years of a bed system of Crispin/M27 apple trees at four spacings. J. Appl. Ecol. 25:569-578.

Palmer, J.W., J.N. Wünsche, M. Meland, and A. Hann. 2002. Annual dry matter production by three apple cultivars at four within-row spacings in New Zealand. J. Hort. Sci. Biotechnol. 77:712-717.

Preston, A.P. 1954. Effects of fruit thinning by the leaf count method on yield, size and biennial bearing of the apple Duchess Favorite. J. Hort. Sci. 29:269-277.

Robinson, T.L., J. Schupp, M. Fargione, and J. Osborne. 2005. Growing large 'Gala' apples. Compact Fruit Tree 38:2-5.

Wünsche, J.N. and J.W. Palmer. 2000. Effects of crop load on fruiting and gas exchange characteristics of 'Braeburn'/M.26 apple tree at full canopy. J. Amer. Soc. Hort. Sci. 125:93-99. 